\title{
Financial performance, corporate governance, and financial distress
}

\author{
Endang Ernawati, Samantha Elysia Handojo, \& Werner Ria Murhadi \\ University of Surabaya, Surabaya, Indonesia
}

\begin{abstract}
This study aims to analyze the effect of financial ratios and corporate governance on financial distress by making a prediction model of bankruptcy using data from non-financial sector companies listed on the Indonesia Stock Exchange (IDX). This research used the quantitative approach with a logistic regression model. The samples used in this study were 310 companies from the non-financial sector with 1550 observations. The research findings suggested that the variables included in the model are current liabilities to total assets, total liabilities to total assets, book-to-market value, blockholder ownership, sales to total assets, earnings before interest, and taxes to total assets. While the audit opinion variable has no significant effect. Although not all the variables which have been incorporated into the model were significant, the insignificant variables still remained in the model to improve the accuracy of the prediction model. The results suggested that the accuracy of this bankruptcy prediction model was $98.1 \%$.
\end{abstract}

Keywords: financial distress, financial ratio, good corporate governance

\section{INTRODUCTION}

Bankruptcy, according to Perpu (Government Regulation in lieu of Law) No. 1 year 1998 is a debtor who has two or more creditors and fails to pay at least one overdue debt and collectible, shall be declared bankrupt by authorized court decision either by his own request or by the request of one or more creditor(s). Liang et al. (2016) suggested that bankruptcy or business failure of an enterprise brings a negative impact for both the entreprise and global economy. The impact of corporate bankruptcy for both local and global economy has led to the importance of accurate bankruptcy prediction models. Altman (1968) conducted a preliminary study that utilized financial ratio analysis to predict bankruptcy using the Multiple Discriminant Analysis (MDA) method. Subsequently, many similar studies were conducted to develop a more accurate bankruptcy prediction model. A recent study combines Good Corporate Governance (GCG) with Financial Ratio (FR's) as the independent variables to predict financial distress. Liang et al. (2016) in their study suggested that bankruptcy prediction model which combines between FR's and GCG is more accurate than the one which uses either FR's or GCG only.

Based on Liang et al. finding, this study combined some of previous studies that used either FR's or GCG only as their independent variable to predict financial distress.

Table 1. The Results of Financial Ratio Impact on Financial Distress

\begin{tabular}{|c|c|c|c|c|c|}
\hline No & $\begin{array}{c}\text { Independent } \\
\text { Variable }\end{array}$ & $\begin{array}{l}\text { Roslan } \\
(2015)\end{array}$ & $\begin{array}{l}\text { Mousavi } \\
\text { et al. } \\
(2015)\end{array}$ & $\begin{array}{l}\text { Sumitro } \\
(2012)\end{array}$ & $\begin{array}{c}\text { Kordlar } \\
\& \text { Nik- } \\
\text { bakht } \\
(2013)\end{array}$ \\
\hline & \multicolumn{5}{|l|}{ Liquidity Ratio: } \\
\hline 1 & $\mathrm{WC} / \mathrm{TA}$ & Sig (-) & $\operatorname{Sig}(+)$ & $\operatorname{Sig}(+)$ & - \\
\hline 2 & \multicolumn{5}{|l|}{ Leverage Ratio: } \\
\hline 3 & CL/TA & - & - & $\operatorname{Sig}(+)$ & - \\
\hline 4 & TL/TA & $\operatorname{Sig}(+)$ & Sig (-) & - & - \\
\hline 5 & \multicolumn{5}{|c|}{ Activity Ratio: } \\
\hline 6 & \multicolumn{5}{|c|}{ Profitability Ratio: } \\
\hline 7 & NI/TA & $\operatorname{Sig}(+)$ & - & Sig (-) & - \\
\hline 8 & $\mathrm{~EB} / \mathrm{TA}$ & Sig (-) & - & - & - \\
\hline 9 & $\mathrm{RE} / \mathrm{TA}$ & - & - & - & Sig (-) \\
\hline 10. & $\begin{array}{l}\text { Market Ratio: } \\
\text { BV/MV }\end{array}$ & $\operatorname{Sig}(+)$ & - & - & - \\
\hline
\end{tabular}

Table 1 summarizes the results of Roslan (2015), Mousavi et al. (2015), Sumitro (2012), \& Kordlar \& Nikbakht (2013) which used FR's as their indepen- 
dent variable to predict financial distress. While, table 2 summarizes the results of Manzaneque et al. (2016), Chan et al. (2016), \& Miglani et al. (2015) which used GCG as their independent variable to predict financial distress. This study combined both FR's and GCG as its variables to predict financial distress in order to obtain a more accurate result as suggested by Liang et al. (2016).

Table 2. The Results of GCG Impact on Financial Distress

\begin{tabular}{clccc}
\hline No & $\begin{array}{c}\text { Independent } \\
\text { variable }\end{array}$ & $\begin{array}{c}\text { Manzaneque } \\
\text { et al. (2016) }\end{array}$ & $\begin{array}{c}\text { Chan } \\
\text { et al. } \\
(2016)\end{array}$ & $\begin{array}{c}\text { Miglani et } \\
\text { al. (2015) }\end{array}$ \\
\hline 1 & Dir_Own & Sig (-) & Insig (-) & Sig (-) \\
2 & Dir_Size & Sig (-) & Sig (+) & - \\
3 & Block_Own & Insig (+) & - & Sig (-) \\
4 & Ind_Com & Sign (-) & - & Insig (-) \\
5 & Audit_Opn & - & - & Sig (+) \\
\hline
\end{tabular}

Referring to the previous studies, this study used independent variables in the category of FR's include working capital to total asset (WC/TA), cash to total asset (C/TA), current liabilities to total asset (CL/TA), total liabilities to total asset (TL/TA), inventory to working capital (I/WC), sales to total asset (S/TA), net income to total asset (NI/TA), earnings before interest and taxes to total asset (EB/TA), retained earnings to total asset RE/TA), and book-tomarket value (BV/MV). While the independent variables in the GCG category include director ownership (DIR_ OWN), director size (DIR_SIZE), blockholder ownership (BLOCK_OWN), independent directors (IND_COM), and audit opinion (AUDIT_OPN).

The study aims to create bankruptcy prediction model using both financial ratios (FR's) and good corporate governance (GCG) variables for nonfinancial sector companies listed on Indonesia Stock Exchange over the period of 2012-2016.

\section{RESEARCH METHODS}

This research was a basic research study using quantitative approach. The population of this study was 522 companies that listed on the Indonesia Stock Exchange per December 2016. The target population was 310 companies from non-financial and investment sectors which do not issue initial public offerings (IPO), have complete financial statements, do not do stock split, and have their financial statement ending in December. This study used secondary data obtained from various sources. The financial statement and closing price were taken from Indonesia
Stock Exchange (www.idx.co.id) and Indonesian Capital Market Directory (www.ticmi.co.id), while information on IPO and stock split dates were taken from www.britama.com.

The level of measurement of the dependent variable (financial distress) is nominal. The level of measurement of the independent variable (financial distress) is ratio, except for audit opinion (AUDIT_OPN).

In order to create prediction model, Multivariate Discriminant Analysis (MDA) was used. MDA can be used if the group covariance matrices are equal, proven with the test of equality group matrices and the data are in normal distribution. The model of MDA that can be formulated based on the used independent variable are as follows:

$$
\begin{aligned}
\mathrm{Z}=\mathrm{V} 1 \mathrm{WC} / \mathrm{TAie} & +\mathrm{V} 2 \mathrm{C} / \mathrm{TAie}+\mathrm{V} 3 \mathrm{CL} / \mathrm{TAie} \\
& + \text { V4TL/TAie + V5RE/TAie + V6I/WCit } \\
& + \text { V7S/TAie + V8NI/TAit + V9EB/TAit } \\
& + \text { V10BT/MVit + V11B0ARDOWNit } \\
& + \text { V12BSit + V13BLOCKOWNit } \\
& + \text { V14IDit + V15AUDITOPNit }
\end{aligned}
$$

Logistic regression model is used when group covariance matrices are not equal and the data are not in normal distribution. The model that can be established based on independent variable used are as follows:

$$
\begin{aligned}
\operatorname{Ln}[\mathrm{P} /(1-\mathrm{P})] & =\mathrm{a}+\mathrm{b} 1 \mathrm{WC} / \mathrm{TAie}+\mathrm{b} 2 \mathrm{C} / \mathrm{TAie} \\
& +\mathrm{b} 3 \mathrm{CL} / \mathrm{TAie}+\mathrm{b} 4 \mathrm{TL} / \mathrm{TAie} \\
& +\mathrm{b} 5 \mathrm{RE} / \mathrm{TAi}+\mathrm{b} 6 \mathrm{I} / \text { WCit }+\mathrm{b} 7 \mathrm{~S} / \mathrm{TAie} \\
& +\mathrm{b} \text { 8NI/TAit }+\mathrm{b} 9 \mathrm{~EB} / \mathrm{TAit} \\
& +\mathrm{b} 10 \mathrm{BT} / \mathrm{MVit}+\mathrm{b} 11 \text { BOARDOWNit } \\
& +\mathrm{b} 12 \mathrm{BSit}+\mathrm{b} 13 \text { BLOCKOWNit } \\
& +\mathrm{b} 14 \text { INDCOMit }+ \text { b15AUDITOPNit }
\end{aligned}
$$

\section{RESULTS AND DISCUSSION}

This study used logistic regression model because the required assumption of the MDA model is not fulfilled. The number of observation in this study was 1550 .

Table 3. Model Summary

\begin{tabular}{cccc}
\hline Step & $\begin{array}{c}-2 \text { Log } \\
\text { likelihood }\end{array}$ & $\begin{array}{c}\text { Cox \& Snell } \\
\text { R Square }\end{array}$ & $\begin{array}{c}\text { Nagelkerke } \\
\text { R Square }\end{array}$ \\
\hline 1 & $576.473^{\mathrm{a}}$ & .095 & .252 \\
\hline
\end{tabular}

Note: a. Estimation terminated at iteration number 7 because parameter estimates changed by less than .001 . 
In table 3, the value of Nagelkerke $\mathrm{R}$ Square is $25.2 \%$. This value can be interpreted to be equal to $\mathrm{R}^{2}$ in ordinary least square (OLS). This finding shows that the variability of an independent variable indicates the variability of financial distress variable is $25.2 \%$. The fit model was tested using Hosmer and Lemeshow test that assesses null hypothesis. If null hypothesis is accepted, the empirical data fit the model.Table 4 shows Chi-square of 157.626 with 0.000 significance which means null hypothesis is rejected. The model cannot predict its observation value. In order to overcome this problem, outliers in the data are removed. Observation value becomes 1435 data and Nagelkerke R Square value becomes $68.4 \%$ higher than the one before, $25.2 \%$. This finding shows that the variability of the independent variable indicates the variability of financial distress variable is $68.4 \%$. Chi-square becomes 0.952 with 0.999 significance or $5 \%$ higher. Thus, null hypothesis is accepted and the model predicts the observation value, in other words, the model fits with the observation data.

Table 4. Hosmer and Lemeshow Test

\begin{tabular}{cccc}
\hline Step & Chi-square & df & Sig. \\
\hline 1 & 157.626 & 8 & .000 \\
\hline
\end{tabular}

Source: Analyzed using SPSS 18.0

This study uses backward stepwise (conditional) whereas the insignificant variables will be removed gradually to get a model that consists of significant variables. Table 5 shows some corresponding variables included in the financial distress model: CL/TA, TL/TA, BV/MV, and BLOCK_OWN which have positive impact towards financial distress. Thus, the higher the ratio, the higher the financial distress to occur. On the other hand, S/TA, EB/TA, and DIR_OWN have negative impact towards financial distress. Thus, the higher the ratio, the lower the financial distress to occur. The AUDITOPN variable has no significant effect in the model. However, these variables remain incorporated to maintain the accuracy of financial distress prediction models.

Table 5. Variables Used in The Financial Distress Model

\begin{tabular}{lrr}
\hline \multicolumn{1}{c}{ Independent Variable } & Coefficient & \multicolumn{1}{c}{ Significant } \\
\hline CL/TA & 1,507 & $0,079^{*}$ \\
TL/TA & 1,637 & $0,000^{* * *}$ \\
S/TA & $-6,162$ & $0,000^{* * *}$ \\
EB/TA & $-25,262$ & $0,000^{* * *}$ \\
BV/MV & 0,240 & $0,004 * * *$ \\
DIR_OWN & $-13,958$ & $0,011^{* *}$ \\
BLOCK_OWN & 2,265 & $0,044^{* *}$ \\
\hline
\end{tabular}

Table 5, cont.

\begin{tabular}{lrl}
\hline AUDIT_OPN & $-39,740$ & 0,995 \\
Constant & $-5,220$ & 0,000 \\
\hline
\end{tabular}

* Sig 10\%, ** Sig 5\%, *** Sig 1\%

Financial distress model is formulated as follows:

$$
\begin{aligned}
& \text { Ln }[\mathrm{P} /(1-\mathrm{P})] \\
& =-5,220+1,507 \mathrm{CL} / \mathrm{TA} \\
& +1,637 \mathrm{TL} / \mathrm{TA}-6,162 \mathrm{~S} / \mathrm{TA}-25,262 \mathrm{~EB} / \mathrm{TA} \\
& +0,240 \mathrm{BV} / \mathrm{MV}-13,958 \text { DIR_OWN } \\
& +2,265 \text { BLOCK_OWN }-39,740 \text { AUDIT_OPN }
\end{aligned}
$$

Or

$$
\begin{aligned}
& \mathrm{P} /(1-\mathrm{P}) \\
& =\mathrm{e}-5,220+1,507 \mathrm{Cl} / \mathrm{TA} \\
& +1,637 \mathrm{TL} / \mathrm{TA}-6,162 \mathrm{~S} / \mathrm{TA}-25,262 \mathrm{~EB} / \mathrm{TA} \\
& +0,240 \mathrm{BV} / \mathrm{MV}-13,958 \mathrm{DIR} \text {-OWN } \\
& +2,265 \text { BLOCK_OWN }-39,740 \text { AUDIT_OPN } \\
& \text { Note: } \\
& \text { Ln = Natural logarithm } \\
& \mathrm{P}=\text { Probability } \\
& \mathrm{E}=\text { Real constant number that closes to } 2.71828
\end{aligned}
$$

From the 1396 data entered into the non-distress category, there were 1388 data consistent in the nondistress category $(99.40 \%)$, while the other 8 data were classified into the distress category $(0.60 \%)$. Likewise, in 39 company data classified in the distress category, the prediction indicates that there are 20 data consistent in the distress category $(51.30 \%)$, while the other 19 data were classified into the nondistress category $(48.70 \%)$. The overall prediction accuracy is $98.1 \%$. This shows the model has good predictive validity because the classification rate obtained far exceeds $50 \%$.

CL/TA has an insignificant positive effect on financial distress with a significance of 0.079 . The result of this study is not in line with the hypothesis that has been formulated and the results of Sumitro (2012) in which CL/TA has a significant positive effect on financial distress. This indicates that the value of current debt is not significant enough to affect financial distress.

TL/TA has a significant positive effect on financial distress. The greater the total debt, the higher the chances of the company in experiencing financial distress because the risk of default is also high. This result is in accordance with Roslan's (2015).

S/TA has a significant negative effect on financial distress. Liana \& Sutrisno (2014) suggests that sales reflect the company's ability to maintain its competitive position. Sales decrease does not necessarily make the company go bankrupt, but only reduce the profit. As long as the decrease is still reasonable or is part of the business cycle, then it will not cause problems that make the company directly experience financial distress. In addition, the decrease can also 
be caused by temporary external factors, such as economic, political, climate change, bad weather, and so on, which are also experienced by other companies and do not always result in financial distress. The result of this study is not in line with the hypothesis that has been formulated and the results of Sumitro (2012) which utters that S/TA has a significant negative effect on financial distress.

EB / TA negatively affects financial distress with a significance of 0.000 . EB/TA is used to find out how effective a company uses its assets in generating profit before paying the contractual obligation. In addition, this ratio indicates the company's capacity to generate profits to pay off its fixed liabilities, i.e. interest on loans. Thus, the greater the EB/TA, the lower the financial distress to happen. The result of this study is in accordance with the hypothesis that has been proposed and supported by the Roslan's (2015) which states the significant negative influence of EB / TA on financial distress.

$\mathrm{BV} / \mathrm{MV}$ has a significant positive effect on financial distress. Book value greater than market value indicates that the company is in a less healthy condition, thereby increasing financial distress. This result is in accordance with the hypothesis that has been developed and supported by the results of Roslan (2015).

Director Ownership (Dir_Own) has a negative effect on financial distress with a significance of 0.011 . The result of this study is in accordance with the hypothesis that has been formulated and supported by the results of Manzaneque et al. (2016) and Miglani et al. (2015) where Dir_Own has a significant negative effect on financial distress. Indeed, the purpose of giving ownership of shares to the board of directors is to align interests with shareholders.

Blockholder ownership (Block_Own) has a positive influence on financial distress which indicates the greater the blockholder ownership, the higher the financial distress. Parulian (2007) mentioned that blockholder ownership has a positive influence on financial distress. Majority shareholders have the probability of taking over the wealth of minority shareholders. Reddy et al. (2015) have reported evidence that blockholders receive personal benefits at the expense of minority shareholders' interests. The concentration of ownership may also generate asymmetric information between majority and minority shareholders (Jensen 1993).

Audit opinion (Audit_Opn) has no significant effect on financial distress which means that the result of the auditor's opinion does not cause the company to become unhealthy. For example, PT. Gozco Plantations, Tbk. in 2014-2015 received an audit result of
1 which means it does not meet unqualified opinion criteria, but the company's condition is healthy.

\section{CONCLUSION}

From the logistic regression analysis using the backward elimination (conditional) method, there are eight variables included in the financial distress model: CL/TA, TL/TA, S/TA, EB/TA, BV/MV, Dir_Own, Block_Own, and Audit_Opn.

Two insignificant variables, CL/TA and $\mathrm{Au}-$ dit_Opn are still included to support or maintain the accuracy of the prediction model. From the results of data processing, it is obtained that the financial distress model is able to predict the financial distress of non-financial and investment companies with an accuracy of $98.1 \%$.

\section{REFERENCES}

Altman, E.I. 1968. Financial ratio discriminant analysis and the prediction of corporate bankruptcy. Journal of Finance 23: 589-609.

Chan, C.Y., Chou, D.W., Lin, J.R. \& Liu, F.Y. 2016. The role of corporate governance in forecasting bankruptcy: Pre and Post SOX enactment. North American Journal of Economic and Finance 35: 166-188.

Jensen, M.C. 1993. The modern industrial revolution, exit and the failure of internal control systems. The Journal of Finance 48(3): 831-880.

Kordlar, A.E., \& Nikbakht, N. 2011. Comparing bankruptcy prediction model in Iran. Business Intelligence Journal 4(2): 335-342.

Sutrisno, D.L. 2014. Analisis rasio keuangan untuk memprediksi kondisi financial distress perusahaan manufaktur. Jurnal Studi Manajemen dan Bisnis 1(2).

Liang, D., Lu, C.C., Tsai, C.F. \& Shih, G.A. 2016. Financial ratios and corporate governance indicators in bankruptcy prediction: A Comprehensive Study. European Journal of Operational Research 000: 1-12.

Manzaneque, M., Alba M. Priego, \& Elena Merino. 2016. corporate governance effect on financial distress likelihood: evidence from Spain, Revista de Contabilidad - Spanish Accounting Review 19: 111-121.

Miglani, S., Ahmed, K. \& Henry, D. 2015. Voluntary corporate governance structure and financial distress: evidence from Australia. Journal of Contemporary Accounting \& Economics 11: 18-30

Mousavi, M.M., Ouenniche, J. \& Bing-Xu. 2015. Performance evaluation of bankruptcy prediction models: an orientation free super efficiency DEA based framework. International Review of Financial Analysis 42: 64-75.

Parulian, S.R. 2007. Hubungan struktur kepemilikan, komisaris independen dan kondisi financial distress perusahaan publik. Jurnal Akuntansi dan Keuangan 1(3): 263-274.

Reddy, K.S., Abidin, S., He, W. \& Sinha, P. 2015. Does ownership identity of blockholders matter: an empirical of publicy listed companies in New Zealand, Asian Journal of Finance \& Accounting 7(1): 13-44.

Roslan, N.H.B. 2015. Determinants of financial distress among manufacturing companies in Malaysia (unpublished Master). Universiti Utara Malaysia. Malaysia

Sumitro, F. 2012. Permodelan financial distress pada badan 
usaha sektor manufaktur yang terdaftar di Bursa Efek Indonesia periode 1999-2010 (unpublished thesis). Universitas Surabaya. Surabaya. 